\title{
The Effects of Distraction on Preoperative Anxiety in Preschool and School-Age Children: A Literature Review
}

\author{
By Shahla Abdul Wahid ${ }^{*}$ Swapna Johncy ${ }^{ \pm}$Sadaf Abbas ${ }^{*}$ \& \\ Mikyoung Lee ${ }^{+}$
}

\begin{abstract}
Children experience high levels of anxiety before surgery. Preoperative anxiety interferes with anesthesia induction compliance and is associated with many short and long-term postoperative complications The aim of this integrative review was to evaluate the impact of distraction methods on preoperative anxiety in preschool and school-age children compared to standard of care or conventional methods. A systematic search of literature was conducted using PubMed and CINHAL databases. We found 15 full-text articles in English published, between the years 2015-2019 on preschool and school-age children on PubMed, CINHAL, and keyword search according to inclusion criteria. The tools used to measure the children's anxiety included a personal information from, separation scoring, index of clinical stress score, modified Yale preoperative assessment scale, the state-trait anxiety inventory for children, post hospitalization behavior questionnaire, Hamilton anxiety rating scale, and vital signs. Medical clowns, integrated art therapy, therapeutic play, "Play-doh", computer games, books, and music, video games, toys, music, books, virtual reality, smartphone, relaxation-guided imagery, and iPads were used for creating distraction to reduce anxiety levels during parental separation and the preoperative period. Distraction is a safe, timely, and cost-effective non-pharmacological anxiolytic intervention that can be performed by nurses.
\end{abstract}

Keywords: distraction, therapy, art, anxiety, play, surgery

\section{Introduction}

Aim

The aim of this integrative literature review was to identify the effectiveness of distraction interventions in reducing preoperative anxiety in children and discuss the methods available for evidence-based preparation of children undergoing surgery. We examined the various distraction interventions employed, and different methodological approaches utilized to evaluate the effects of those distraction interventions on levels of anxiety in preoperative children, compared to pharmacological interventions in the surgical setting.

\footnotetext{
*PhD Student, Texas Woman's University, USA.

${ }^{ \pm} \mathrm{PhD}$ Student, Texas Woman's University, USA.

†PhD Student, Texas Woman's University, USA.

+Associate Professor, Texas Woman's University, USA.
} 


\section{Scope of Research}

A systematic search was conducted for peer reviewed articles published in academic journals on the topic of distraction as an intervention to reduce preoperative anxiety in children between the ages of three and 12 years.

The Inclusion Criteria and Justification

We included full texts of any studies that implemented and measured the effects of distraction techniques to reduce preoperative anxiety of children. The patient population was preschool and school-age children, specifically three to 12 years of age.

\section{The Exclusion Criteria and Justification}

Books, editorial reviews, commentaries, systematic protocols were excluded to allow for currency and evidence-based outcomes. Dissertations were excluded because they consist mostly of unpublished research studies, as well as studentconducted studies of poor quality. Children of age less than three years and greater than 12 were excluded to allow for targeted interventions based on Erikson's stages of psychosocial development.

\section{Literature Review}

The findings of the literature review have been summarized in Table 1 .

\section{Research Question}

Can distraction techniques (I) reduce preoperative anxiety in children 3-12 years old (O) compared to pharmacological interventions $(\mathrm{C})$ in the surgical setting $(\mathrm{P})$ ? 
Table 1. Literature Review Table

\begin{tabular}{|c|c|c|c|c|c|c|}
\hline \multirow{2}{*}{$\begin{array}{l}\text { Authors } \\
\text { (Publication } \\
\text { Year) }\end{array}$} & \multirow{2}{*}{$\begin{array}{l}\text { Sample } \\
\text { and } \\
\text { Setting }\end{array}$} & \multirow[b]{2}{*}{$\begin{array}{l}\text { Study } \\
\text { Design }\end{array}$} & \multicolumn{2}{|c|}{ Interventions } & \multirow[b]{2}{*}{ Measures } & \multirow[b]{2}{*}{ Results } \\
\hline & & & $\begin{array}{c}\begin{array}{c}\text { Distraction } \\
\text { group }\end{array} \\
\end{array}$ & Control group & & \\
\hline $\begin{array}{l}\text { Vagnoli et al. } \\
\text { (2019, pp. } \\
\text { 913-921). }\end{array}$ & $\begin{array}{l}\text { Study } \\
\text { group } \\
\mathrm{N}=30 . \\
\text { Control } \\
\text { group } \\
\mathrm{N}=30 . \text { Age } \\
\text { 6-12 yrs. } \\
\text { Children's } \\
\text { hospital in } \\
\text { Florence, } \\
\text { Italy. }\end{array}$ & $\begin{array}{l}\text { Randomized } \\
\text { Control Trial } \\
\text { (RCT) }\end{array}$ & $\begin{array}{l}\text { Relaxation } \\
\text { guided imagery } \\
\text { and parental } \\
\text { accompaniment }\end{array}$ & $\begin{array}{l}\text { Standard care } \\
\text { and parental } \\
\text { accompaniment. }\end{array}$ & $\begin{array}{l}\text { The Italian } \\
\text { translation of } \\
\text { the m_YPAS } \\
\text { The results } \\
\text { showed that the } \\
\text { study group } \\
\text { experienced } \\
\text { significantly } \\
\text { less } \\
\text { preoperative } \\
\text { anxiety than the } \\
\text { control group } \\
\text { (P<0.001) } \\
\text { especially with } \\
\text { subjects with a } \\
\text { history of } \\
\text { previous } \\
\text { surgery. Post- } \\
\text { operative pain } \\
\text { was also lower } \\
\text { in the study } \\
\text { group. } \\
\text { Level of } \\
\text { evidence } \\
\text { Translation of } \\
\text { m-YPAS } \\
\text { used to meas } \\
\text { anxiety during } \\
\text { induction by } 2 \\
\text { trained } \\
\text { psychologists } \\
\text { (FLACC } \\
\text { scale the } \\
\text { to assess used } \\
\text { postoperative } \\
\text { pain. } \\
\text { outline care, } \\
\text { i.e., } \\
\text { accompanied by } \\
\text { a parent who } \\
\text { stayed with } \\
\text { them till } \\
\text { anesthesia } \\
\text { induction. }\end{array}$ & $\begin{array}{l}\text { The results } \\
\text { showed that the } \\
\text { study group } \\
\text { experienced } \\
\text { significantly less } \\
\text { preoperative } \\
\text { anxiety than the } \\
\text { control group } \\
\text { (P<0.001) } \\
\text { especially with } \\
\text { subjects with a } \\
\text { history of previous } \\
\text { surgery. Post- } \\
\text { operative pain was } \\
\text { also lower in the } \\
\text { study group. } \\
\text { Level of evidence } \\
\text { A. }\end{array}$ \\
\hline
\end{tabular}




\begin{tabular}{|c|c|c|c|c|c|c|}
\hline $\begin{array}{l}\text { Franzoi et al. } \\
(2016, p \text {. } \\
\text { e2841) }\end{array}$ & $\begin{array}{l}\text { Study } \\
\text { group } \\
\mathrm{N}=26 . \\
\text { Control } \\
\text { group } \\
\mathrm{N}=26 . \\
\text { Age 3-12. } \\
\text { Pediatric } \\
\text { Surgical } \\
\text { Unit at a } \\
\text { public } \\
\text { hospital. } \\
\text { Brasilia, } \\
\text { Brazil. }\end{array}$ & RCT & $\begin{array}{l}\text { Fifteen minutes } \\
\text { of music } \\
\text { listening. }\end{array}$ & $\begin{array}{l}\text { Routine care, } \\
\text { i.e., } \\
\text { accompanied by } \\
\text { a parent who } \\
\text { stayed with them } \\
\text { until anesthesia } \\
\text { induction. }\end{array}$ & $\begin{array}{l}\text { m-YPAS }{ }^{3} \text { and } \\
\text { measurement } \\
\text { of the } \\
\text { physiological } \\
\text { variables, upon } \\
\text { arrival and } 15 \\
\text { minutes after } \\
\text { the first } \\
\text { measurement. }\end{array}$ & $\begin{array}{l}\text { There was a } \\
\text { significant } \\
\text { reduction in post- } \\
\text { intervention } \\
\text { physiological } \\
\text { markers of } \\
\text { anxiety in school- } \\
\text { age children } \\
\text { belonging to the } \\
\text { study group, as } \\
\text { compared to pre- } \\
\text { school children in } \\
\text { the study group, } \\
\text { and all children in } \\
\text { the control group. } \\
\text { The m-YPAS } \\
\text { scores in all } \\
\text { categories were } \\
\text { lower for the } \\
\text { study group, as } \\
\text { compared to the } \\
\text { control group, } \\
\text { post-intervention. } \\
\text { There was } \\
\text { attrition in sample } \\
\text { size as well as a } \\
\text { violation of } \\
\text { exclusion criteria. } \\
\text { Level of evidence } \\
\text { A. }\end{array}$ \\
\hline $\begin{array}{l}\text { Marechal et al. } \\
\text { (2017,pp. } \\
\text { 247-253). }\end{array}$ & \begin{tabular}{|l|} 
Study group \\
$\mathrm{N}=60$. Control \\
group N=58. \\
Age 4-11 \\
Children's \\
hospital in \\
Lyon, \\
France.
\end{tabular} & RCT & $\begin{array}{l}\text { iPad electronic } \\
\text { tablet } 20 \\
\text { minutes before } \\
\text { anesthesia. The } \\
\text { patient was } \\
\text { encouraged to } \\
\text { play till loss of } \\
\text { consciousness. }\end{array}$ & $\begin{array}{l}\text { Midazolam } \\
0.3 \mathrm{mg} / \mathrm{Kg} \text { orally } \\
\text { or per rectum, } \\
20-30 \text { minutes } \\
\text { before } \\
\text { anesthesia } \\
\text { (standard } \\
\text { procedure). }\end{array}$ & $\begin{array}{l}\text { m-YPAS }{ }^{3} \text { and } \\
\text { STAI-C }{ }^{2} \text { were } \\
\text { used to } \\
\text { measure } \\
\text { anxiety while } \\
\text { in the waiting } \\
\text { surgical area, } \\
\text { at the time of } \\
\text { separation } \\
\text { from parents, } \\
\text { during } \\
\text { anesthesia } \\
\text { induction, and } \\
\text { when back in } \\
\text { the ambulatory } \\
\text { surgery ward }\end{array}$ & $\begin{array}{l}\text { Both m-YPAS }{ }^{3} \text { and } \\
\text { STAI-C }{ }^{2} \text { were } \\
\text { very similar for } \\
\text { both the study } \\
\text { group and the } \\
\text { control group at all } \\
4 \text { points of } \\
\text { measurement. } \\
\text { Nurses and parents, } \\
\text { however, } \\
\text { expressed more } \\
\text { satisfaction with } \\
\text { anesthesia } \\
\text { procedures for the } \\
\text { study group. } \\
\text { Level of evidence } \\
\text { A. }\end{array}$ \\
\hline $\begin{array}{l}\text { yu et al. (2018, } \\
\text { p. } 284) .\end{array}$ & $\begin{array}{l}\text { Study } \\
\text { Group } \\
\mathrm{N}=34 \\
\text { Control } \\
\text { group } \\
\mathrm{N}=35, \\
\text { Age 5-8 } \\
\text { years } \\
\text { Seoul } \\
\text { National } \\
\text { University } \\
\text { Bundang } \\
\text { Hospital, } \\
\text { Seoul, S. } \\
\text { Korea }\end{array}$ & RCT & $\begin{array}{l}\text { Played } 5 \\
\text { minutes of VR } \\
\text { game, } 1 \text { hour } \\
\text { preoperatively. } \\
\text { Children are } \\
\text { encouraged to } \\
\text { ask questions } \\
\text { about the } \\
\text { procedure and } \\
\text { anesthesia. }\end{array}$ & $\begin{array}{l}\text { Routine } \\
\text { preoperational } \\
\text { education and } \\
\text { care. }\end{array}$ & $\begin{array}{l}\text { m-YPAS } \\
\text { assessment } \\
\text { was performed } \\
\text { by a single- } \\
\text { blinded } \\
\text { evaluator. }\end{array}$ & $\begin{array}{l}\text { There was no } \\
\text { significant } \\
\text { difference } \\
\text { between the two } \\
\text { groups at } \\
\text { baseline. The } \\
\text { change in the } \\
\text { score of the study } \\
\text { group, in } \\
\text { comparison to the } \\
\text { control group, } \\
\text { after the } \\
\text { intervention was } \\
\text { significant } \\
\text { P=0.002. } \\
\text { Level of evidence } \\
\text { A. }\end{array}$ \\
\hline
\end{tabular}




\begin{tabular}{|c|c|c|c|c|c|c|}
\hline $\begin{array}{l}\text { Kim et al. } \\
\text { (2015, pp. } \\
778-784) .\end{array}$ & $\begin{array}{l}\text { Video } \\
\text { distraction } \\
\text { group } \\
\text { (group V) } \\
\mathrm{N}=34 \\
\text { Parental } \\
\text { presence } \\
\text { group } \\
\text { (group P), } \\
\mathrm{N}=33 \\
\text { Combinati } \\
\text { on of } \\
\text { video } \\
\text { distraction } \\
\text { plus } \\
\text { parental } \\
\text { presence } \\
\text { group } \\
\text { (group } \\
\text { VP) } \\
\text { N=37 } \\
\text { Age 2 to 7 } \\
\text { Years. } \\
\text { Teaching } \\
\text { Hospital. } \\
\text { Daegu, } \\
\text { Republic } \\
\text { of Korea. }\end{array}$ & RCT & $\begin{array}{l}\text { Group V } \\
\text { Video } \\
\text { distraction only. } \\
\text { Group P } \\
\text { Parental } \\
\text { presence only. } \\
\text { Group VP } \\
\text { Combination of } \\
\text { parental } \\
\text { presence and } \\
\text { video } \\
\text { distraction. } \\
\text { Age 2-7 } \\
\text { A teaching } \\
\text { hospital in South } \\
\text { Korea }\end{array}$ & $\begin{array}{l}\text { There was no } \\
\text { control group. }\end{array}$ & $\begin{array}{l}\text { Preoperative } \\
\text { and } \\
\text { postoperative } \\
\text { anxiety in } \\
\text { parents was } \\
\text { measured by } \\
\text { STA-IC, stress } \\
\text { using the } \\
\text { ICS scale in } \\
\text { children. The } \\
\text { STA-IC, } \\
\text { Ottawa stress } \\
\text { scales, and } \\
\text { Wong-Baker } \\
\text { faces pain scale } \\
\text { were applied }\end{array}$ & $\begin{array}{l}\text { There was very } \\
\text { little difference } \\
\text { between the } \\
\text { anxiety level of } \\
\text { all groups at } \\
\text { baseline or T0. } \\
\text { All groups scored } \\
\text { below } 30 \text { on } \\
\text { m_YPAS which } \\
\text { is the anxiety } \\
\text { cutoff score. At } \\
\text { T1, after the } \\
\text { intervention, the } 3 \\
\text { groups scored } \\
\text { differently. } \\
\text { The children in } \\
\text { Group V (video } \\
\text { distraction only) } \\
\text { demonstrated } \\
\text { lower m-YPAS } \\
\text { scores than the } \\
\text { other } 2 \text { groups. } \\
\text { The overall } \\
\text { increase of m- } \\
\text { YPAS }{ }^{3} \text { score } \\
\text { from T0 to T2 } \\
\text { was similar } \\
\text { Level of evidence } \\
\text { A. }\end{array}$ \\
\hline $\begin{array}{l}\text { Stewart et al. } \\
(2019, \text { pp. } \\
567-575)\end{array}$ & $\begin{array}{l}\text { Study } \\
\text { group } \\
\mathrm{N}=51 . \\
\text { Control } \\
\text { group N = } \\
51 . \text { Age 4- } \\
12 \\
\text { Children's } \\
\text { hospital in } \\
\text { the } \\
\text { Southwest } \\
\text { ern United } \\
\text { States. }\end{array}$ & RCT & $\begin{array}{l}\text { Tablet-based } \\
\text { interactive } \\
\text { distraction } \\
\text { (TBID). Played } \\
\text { age-appropriate } \\
\text { games, selected } \\
\text { by a child life } \\
\text { specialist on an } \\
\text { iPad Mini from } \\
1 \text { minute before } \\
\text { separation (from } \\
\text { parents), till } \\
\text { anesthesia } \\
\text { induction. }\end{array}$ & $\begin{array}{l}\text { Midazolam } \\
0.3 \mathrm{mg} / \mathrm{Kg}, \text { max } \\
20 \mathrm{mg} \text {, orally, } \\
15-45 \text { minutes } \\
\text { before } \\
\text { separation }\end{array}$ & $\begin{array}{l}\text { m-YPAS-SF } \\
\text { (short form) } \\
\text { was used to } \\
\text { assess anxiety. } \\
\text { Interrater } \\
\text { reliability was } \\
\text { obtained after } \\
\text { training } \\
\text { personnel to } \\
\text { use it. } \\
\text { Caregiver } \\
\text { satisfaction } \\
\text { over ease of } \\
\text { child } \\
\text { separation is } \\
\text { rated on a scale } \\
\text { of 0-7 in } \\
\text { recovery. } \\
\text { The PHBQ } \\
\text { was } \\
\text { administered to } \\
\text { parents/caregiv } \\
\text { ers on days } 7 \\
\text { and } 14 \text { post- } \\
\text { surgery to } \\
\text { assess for new- } \\
\text { onset } \\
\text { behaviors. The } \\
\text { PAED7 was } \\
\text { used to } \\
\text { measure } \\
\text { emergence } \\
\text { delirium (ED) } \\
\text { Length of stay } \\
\text { in PACU was } \\
\text { recorded. The } \\
\text { caregiver's } \\
\text { perception of } \\
\text { the child's } \\
\text { level of anxiety } \\
\text { and }\end{array}$ & $\begin{array}{l}\text { The mean total on } \\
\text { m-YPAS-SF } \\
\text { was lower in the } \\
\text { study group at } \\
\text { parental } \\
\text { separation } \\
\text { (P<0.006) and } \\
\text { mask induction } \\
\text { (P<0.001). There } \\
\text { was no difference } \\
\text { at the baseline } \\
\text { (P=0.31). The } \\
\text { PAED score for } \\
\text { the study group } \\
\text { was significantly } \\
\text { lower } 15 \text { minutes } \\
\text { after emergence } \\
\text { (P=.001), while } \\
\text { there was no } \\
\text { significant } \\
\text { difference at } \\
\text { baseline. There } \\
\text { was no significant } \\
\text { difference } \\
\text { between the two } \\
\text { groups in the } \\
\text { parents' rating of } \\
\text { anxiety upon } \\
\text { admission or } \\
\text { separation. The } \\
\text { study group } \\
\text { PACU times } \\
\text { were significantly } \\
\text { shorter, by } 5 \\
\text { minutes to } \\
\text { extubation, } \\
\text { almost } 7 \text { minutes } \\
\text { to arrive at Phase } \\
\text { II, and almost } 25 \\
\text { minutes to }\end{array}$ \\
\hline
\end{tabular}




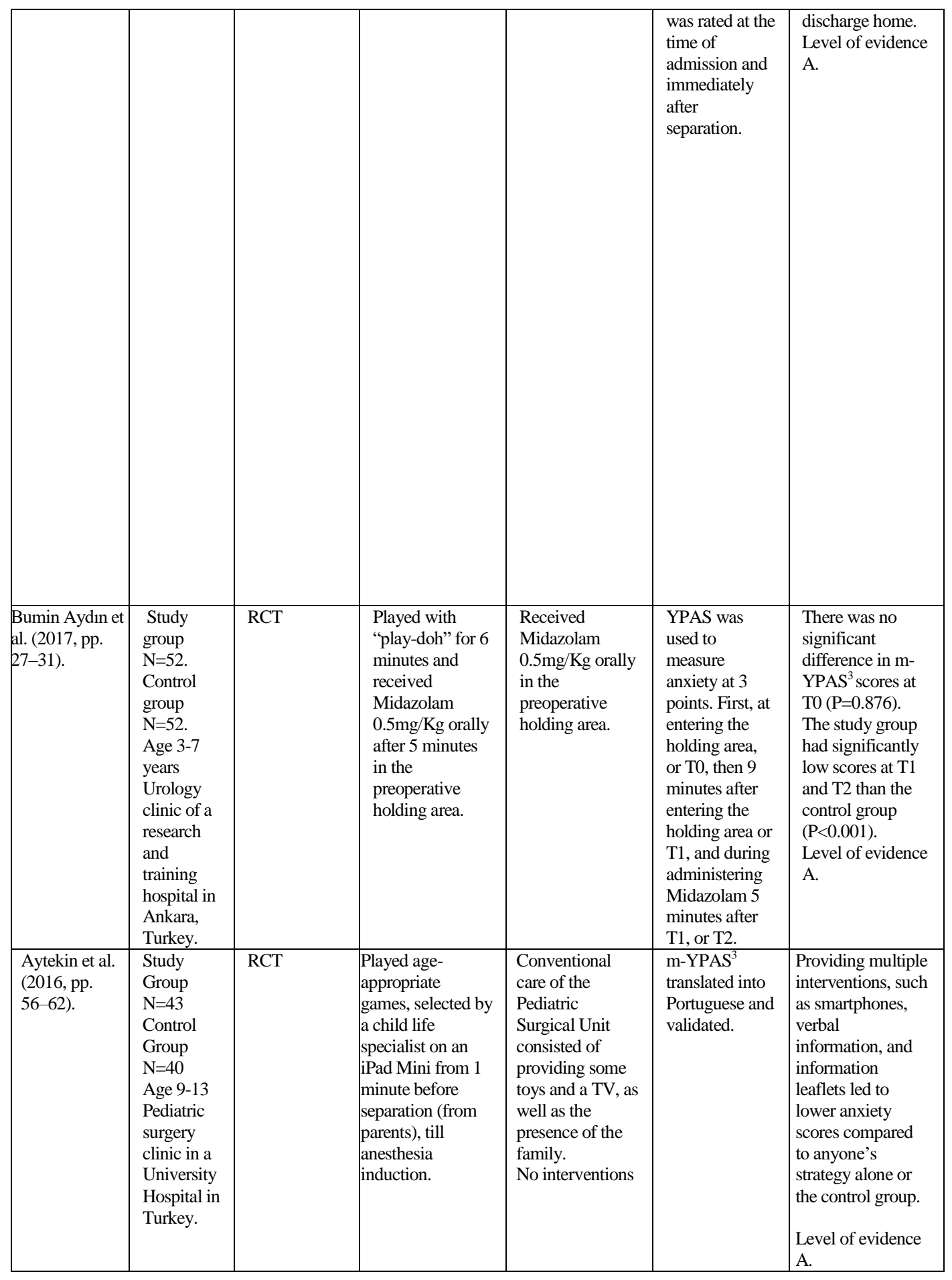




\begin{tabular}{|c|c|c|c|c|c|c|}
\hline $\begin{array}{l}\text { Abd-Elshafy } \\
\text { et al. (2015, } \\
\text { pp. } 1277- \\
1284) .\end{array}$ & $\begin{array}{l}\text { Study group } \\
\mathrm{N}=25 \\
\text { Control } \\
\text { group } \mathrm{N}=25 \text {. } \\
\text { Age 4-12. } \\
\text { Hospital in } \\
\text { Assiut, } \\
\text { Egypt. }\end{array}$ & $\begin{array}{l}\text { Double-blind } \\
\text { RCT }\end{array}$ & $\begin{array}{l}\text { The study group } \\
\text { listened to } \\
\text { recorded favorite } \\
\text { music via } \\
\text { earphones, } \\
\text { starting before } \\
\text { induction of } \\
\text { anesthesia } \\
\text { through } \\
\text { extubation; } \\
\text { Midazolam } \\
0.5 \text { mg/Kg orally } \\
\text { and } 10 \\
\text { micrograms/Kg } \\
\text { of atropine. }\end{array}$ & $\begin{array}{l}\text { Standard care. } \\
\text { Midazolam } \\
0.5 \mathrm{mg} / \mathrm{Kg} \text { orally } \\
\text { and } 10 \\
\text { micrograms } / \mathrm{Kg} \\
\text { of atropine. } \\
\text { The control } \\
\text { group listened to } \\
\text { a blank CD. }\end{array}$ & $\begin{array}{l}\text { The primary } \\
\text { outcomes } \\
\text { measured were } \\
\text { plasma cortisol } \\
\text { and blood } \\
\text { glucose levels } \\
\text { measured at } \\
\text { baseline and } \\
\text { throughout. } \\
\text { The secondary } \\
\text { outcomes } \\
\text { studied related } \\
\text { to anxiety were } \\
\text { child post- } \\
\text { traumatic stress } \\
\text { disorder } \\
\text { (PTSD) } \\
\text { (questionnaire } \\
\text { could not be } \\
\text { matched to any } \\
\text { standardized } \\
\text { PTSD } \\
\text { instruments) } \\
\text { and Post } \\
\text { Hospital } \\
\text { Behavior } \\
\text { Questionnaire } \\
\text { (PHBQ }{ }^{4} \text { ) }\end{array}$ & $\begin{array}{l}\text { Plasma cortisol } \\
\text { levels were lower } \\
\text { in the study } \\
\text { group, especially } \\
\text { at sternotomy; } \\
\text { There was no } \\
\text { statistical } \\
\text { difference } \\
\text { between the } \\
\text { glucose levels of } \\
\text { the two groups. } \\
\text { There were fewer } \\
\text { occurrences of } \\
\text { PTSD9 or } \\
\text { negative } \\
\text { behaviors in the } \\
\text { study group, as } \\
\text { reported by the } \\
\text { authors. } \\
\text { Level of evidence } \\
\text { A }\end{array}$ \\
\hline $\begin{array}{l}\text { Cumino et al. } \\
(2017, \mathrm{pp} . \\
169-175) \text {. }\end{array}$ & $\begin{array}{l}\text { Study } \\
\text { group } \\
\mathrm{N}=21 \text {, } \\
\text { control } \\
\text { group } \\
\mathrm{N}=21 \\
\text { Smartphon } \\
\text { e group, } \\
\mathrm{N}=21 \\
\text { Smartphon } \\
\text { e and } \\
\text { informed } \\
\text { group } \\
\text { N=21 } \\
\text { Age 4-8 } \\
\text { years } \\
\text { tertiary } \\
\text { care } \\
\text { teaching } \\
\text { hospital in } \\
\text { Sau Paulo, } \\
\text { Brazil. }\end{array}$ & RCT & $\begin{array}{l}\text { Informed Group } \\
\text { (IG) Verbal } \\
\text { information } \\
\text { and leaflet for } \\
\text { family. } \\
\text { Smartphone } \\
\text { Group (SG) } \\
\text { Child received } \\
\text { smartphones in } \\
\text { the holding area. } \\
\text { The family } \\
\text { received verbal } \\
\text { information at } \\
\text { the pre-operative } \\
\text { visit. } \\
\text { Smartphone and } \\
\text { informed group } \\
\text { (SIG) Child } \\
\text { received a } \\
\text { smartphone on } \\
\text { the day of } \\
\text { surgery, the } \\
\text { family received } \\
\text { verbal } \\
\text { information and } \\
\text { leaflet. }\end{array}$ & $\begin{array}{l}\text { Received } \\
\text { Midazolam } \\
0.5 \mathrm{mg} / \mathrm{Kg} \text { orally } \\
\text { in the } \\
\text { preoperative } \\
\text { holding area. } \\
\text { The family } \\
\text { received verbal } \\
\text { information } \\
\text { about the } \\
\text { procedure on the } \\
\text { day of surgery. }\end{array}$ & $\begin{array}{l}\text { mYPAS } \\
\text { translated into } \\
\text { Portuguese and } \\
\text { validated. }\end{array}$ & $\begin{array}{l}\text { Providing } \\
\text { multiple } \\
\text { interventions, } \\
\text { such as } \\
\text { smartphones, } \\
\text { verbal } \\
\text { information, and } \\
\text { information } \\
\text { leaflets led to } \\
\text { lower anxiety } \\
\text { scores in the } \\
\text { study group, } \\
\text { compared to } \\
\text { anyone strategy } \\
\text { alone or the } \\
\text { control group. } \\
\text { Level of evidence } \\
\text { A. }\end{array}$ \\
\hline
\end{tabular}




\begin{tabular}{|c|c|c|c|c|c|c|}
\hline $\begin{array}{l}\text { Kumar et al. } \\
(2019, \text { pp. } \\
1244-1250)\end{array}$ & $\begin{array}{l}\text { Study } \\
\text { group } \\
\mathrm{N}=30 \\
\text { Control } \\
\text { Group } \\
\mathrm{N}=30 \\
\text { Age 5-15. } \\
\text { Single- } \\
\text { center } \\
\text { tertiary } \\
\text { teaching } \\
\text { hospital. } \\
\text { New } \\
\text { Delhi, } \\
\text { India. }\end{array}$ & RCT & $\begin{array}{l}\text { Toys and video } \\
\text { games in } \\
\text { children, and } \\
\text { counseling, and } \\
\text { information for } \\
\text { parents. } \\
\text { Promethazine } 1 \\
\text { mg/Kg PO }\end{array}$ & $\begin{array}{l}\text { Promethazine } 1 \\
\mathrm{mg} / \mathrm{Kg} \text { PO }\end{array}$ & $\begin{array}{l}\text { The m-YPAS } \\
\text { was used to } \\
\text { assess anxiety. }\end{array}$ & $\begin{array}{l}\text { Postoperatively, } \\
\text { cortisol levels in } \\
\text { the interventional } \\
\text { group were lower } \\
\text { than the non- } \\
\text { interventional } \\
\text { group. } \\
\text { Providing video } \\
\text { games and toys } \\
\text { preoperatively } \\
\text { reduced } \\
\text { postoperative } \\
\text { stress and anxiety } \\
\text { and improved } \\
\text { mood in children. } \\
\text { Parents were } \\
\text { relieved of } \\
\text { anxiety and stress } \\
\text { with proper } \\
\text { counseling and } \\
\text { information. } \\
\text { Level of evidence } \\
\text { A. }\end{array}$ \\
\hline $\begin{array}{l}\text { Dehghan et } \\
\text { al. (2019, pp. } \\
1-7) \text {. }\end{array}$ & $\begin{array}{l}\text { Study } \\
\text { group 1 } \\
\text { (SG1) } \\
\mathrm{N}=10 ; \\
\text { Study } \\
\text { group 2 } \\
\text { (SG2) N= } \\
\text { 10; } \\
\text { Control } \\
\text { group 1 } \\
\text { (CG1) } \\
\text { N=10; } \\
\text { Control } \\
\text { group 2 } \\
\text { (SG2). } \\
\text { N=10. } \\
\text { Age 6-12 } \\
\text { A teaching } \\
\text { hospital in } \\
\text { Kermansh } \\
\text { ah, Iran. }\end{array}$ & RCT & $\begin{array}{l}\text { SG1 was given } \\
\text { the pretest. } \\
\text { Both groups } \\
\text { filled the post- } \\
\text { test } \\
\text { questionnaire. } \\
\text { Both study } \\
\text { groups received } \\
\text { a tour of the OR } \\
\text { via Virtual } \\
\text { reality } \\
\text { eyeglasses and } \\
\text { earphones and } \\
\text { were immersed } \\
\text { in the sights and } \\
\text { sounds. }\end{array}$ & $\begin{array}{l}\text { CG1 was given } \\
\text { the pretest. } \\
\text { Both groups } \\
\text { filled the post- } \\
\text { test } \\
\text { questionnaire. } \\
\text { Parents were } \\
\text { allowed to touch } \\
\text { and kiss } \\
\text { participants. }\end{array}$ & $\begin{array}{l}\text { The m-YPAS } \\
\text { was used to } \\
\text { assess anxiety. }\end{array}$ & $\begin{array}{l}\text { The children } \\
\text { exposed to VRET } \\
\text { had a significant } \\
\text { reduction in } \\
\text { anxiety scores. } \\
\text { Level of evidence } \\
\text { A. }\end{array}$ \\
\hline $\begin{array}{l}\text { Al-Yateem } \\
\text { et al. } \\
(2016, \mathrm{pp} . \\
572-581)\end{array}$ & $\begin{array}{l}\text { Study } \\
\text { group } \\
\mathrm{N}=84 \\
\text { Control } \\
\text { Group } \\
\mathrm{N}=84 \\
\text { Age } 3-8 \\
\text { Two } \\
\text { private } \\
\text { hospitals, } \\
\text { one in } \\
\text { UAE and } \\
\text { the other } \\
\text { in Jordan. }\end{array}$ & $\begin{array}{l}\text { Randomized } \\
\text { Controlled } \\
\text { non- } \\
\text { inferiority } \\
\text { trial }\end{array}$ & $\begin{array}{l}\text { A custom-made } \\
\text { 'Adam Goes to } \\
\text { Surgery' story } \\
\text { was created and } \\
\text { a coloring book } \\
\text { with scenes from } \\
\text { a typical journey } \\
\text { to the theatre } \\
\text { was used for } \\
\text { distraction. }\end{array}$ & $\begin{array}{l}\text { CG1 was given } \\
\text { the pretest. } \\
\text { Both groups } \\
\text { filled the post- } \\
\text { test } \\
\text { questionnaire. } \\
\text { Parents were } \\
\text { allowed to touch } \\
\text { and kiss } \\
\text { participants. }\end{array}$ & $\begin{array}{l}\text { m-YPAS }{ }^{3} \text { and } \\
\text { the STAI-C } \\
\text { Children's vital } \\
\text { signs were also } \\
\text { collected } \\
\text { preoperatively } \\
\text { during the } \\
\text { induction } \\
\text { period and the } \\
\text { recovery } \\
\text { period. }\end{array}$ & $\begin{array}{l}\text { Interventional } \\
\text { group children } \\
\text { had significantly } \\
\text { less stress, } \\
\text { anxiety, and pain } \\
\text { and improved } \\
\text { mood. } \\
\text { Interventional } \\
\text { group patients } \\
\text { had a significant } \\
\text { reduction in state } \\
\text { anxiety and ICS } \\
\text { score and an } \\
\text { improvement in } \\
\text { mood compared } \\
\text { with the non- } \\
\text { interventional } \\
\text { group. } \\
\text { Level of evidence } \\
\text { B. }\end{array}$ \\
\hline
\end{tabular}




\begin{tabular}{|c|c|c|c|c|c|c|}
\hline $\begin{array}{l}\text { Noronha and } \\
\text { Shanthi } \\
(2015 \text {, pp. } \\
523-525) \text {. }\end{array}$ & $\begin{array}{l}\text { Study } \\
\text { group } \\
\mathrm{N}=15 \\
\text { control } \\
\text { group } \\
\mathrm{N}=15 \\
\text { Age 6-12 } \\
\text { years } \\
\text { undergoin } \\
\text { g surgery } \\
\text { at selected } \\
\text { hospitals } \\
\text { in } \\
\text { Mangalore } \\
\text { India. }\end{array}$ & $\begin{array}{l}\text { Quasi- } \\
\text { experimental } \\
\text { pre-test post- } \\
\text { test control } \\
\text { group design }\end{array}$ & $\begin{array}{l}\text { Picture book and } \\
\text { standard care. }\end{array}$ & Standard care & $\begin{array}{l}\text { Hamilton } \\
\text { anxiety rating } \\
\text { scale (HAM- } \\
\text { A }^{6} \text { ) was used } \\
\text { to assess } \\
\text { anxiety. }\end{array}$ & $\begin{array}{l}\text { During the } \\
\text { pretest, it was } \\
\text { assessed that } 80 \% \\
\text { of the study group } \\
\text { had severe } \\
\text { anxiety, and } 60 \% \\
\text { of the control } \\
\text { group had } \\
\text { moderate to } \\
\text { severe anxiety. In } \\
\text { the post-test, it } \\
\text { was assessed that } \\
\text { only } 53.33 \% \text { of } \\
\text { the study group } \\
\text { participant had } \\
\text { mild to moderate } \\
\text { anxiety, while } \\
73.33 \% \text { of the } \\
\text { control group had } \\
\text { moderate to } \\
\text { severe anxiety. } \\
\text { Level of evidence } \\
\text { C. }\end{array}$ \\
\hline $\begin{array}{l}\text { Dionigi and } \\
\text { Gremigni } \\
(2017, \text { pp. } \\
632-640) .\end{array}$ & $\begin{array}{l}\text { Study } \\
\text { group } \\
\mathrm{N}=37 \\
\text { Control } \\
\text { group } \\
\mathrm{N}=41 \\
\text { Age 3-11 } \\
\text { Public } \\
\text { Hospital in } \\
\text { Northern } \\
\text { Italy. }\end{array}$ & $\begin{array}{l}\text { Observational } \\
\text { Study. }\end{array}$ & $\begin{array}{l}\text { Art therapy and } \\
\text { clown distract }\end{array}$ & $\begin{array}{l}\text { Parental } \\
\text { presence and } \\
\text { Midazolam } \\
\text { orally } 30 \mathrm{~min} \\
\text { preoperatively. } \\
\text { Midazolam } 0.5 \\
\text { mg/Kg by } \\
\text { mouth } 30 \text { min } \\
\text { pre surgery+ } \\
\text { standard }\end{array}$ & $\begin{array}{l}\text { m-YPAS }{ }^{3} \text {. } \\
\text { Parents and } \\
\text { nurses rated } \\
\text { whether } \\
\text { clowns created } \\
\text { any noise in } \\
\text { the } \\
\text { preoperative } \\
\text { holding are } \\
\text { rated on a scale } \\
\text { (1=not at all } \\
\text { helpful- } \\
5=\text { extremely } \\
\text { helpful in } \\
\text { reducing } \\
\text { anxiety); } \\
\text { nurses rated } \\
\text { whether } \\
\text { (yes/no). }\end{array}$ & $\begin{array}{l}\text { Children in the } \\
\text { intervention } \\
\text { group showed } \\
\text { a significant } \\
\text { (p<0.001) } \\
\text { reduction } \\
\text { In m-YPAS } \\
\text { scores at parental } \\
\text { separation } \\
\text { compared to } \\
\text { those in the } \\
\text { control group. } \\
\text { The majority of } \\
\text { parents and } \\
\text { nurses evaluated } \\
\text { the intervention to } \\
\text { be effective for } \\
\text { reducing } \\
\text { children's } \\
\text { anxiety. } \\
\text { Level of evidence } \\
\text { C. }\end{array}$ \\
\hline
\end{tabular}

${ }^{1}$ The evidence level was rated according to the AACN guidelines 2012 (cited in Peterson 2014, p. 62).

${ }^{2}$ State-trait anxiety inventory for children (STAI-C) measures feeling, mood, anger, worry, and stress. The STAI-C state subscale's Chronbach alpha for reliability has been reported to range between $0.71-0.76$. The trait subscale ranges $0.82-0.89$ which indicates high reliability. High concurrent validity has been reported with other valid tests, such as the children's manifest anxiety scale.

${ }^{3}$ Modified Yale preoperative anxiety assessment scale (m-YPAS) is a 27-item checklist divided into 5 categories; Activity, emotional expressivity, state of arousal, vocalization, and use of parents. The total score can range 23.33-100 (a cut-off point of 30 refers to high anxiety). The checklist is appropriate for use with the intra-observer weighted kappa $0.63-0.9$ which is high. ${ }^{4}$ Post hospitalization behavior questionnaire (PHBQ) has 27 items concerning general anxiety and regression, separation anxiety, eating disturbance, aggression, apathy/withdrawal, and anxiety about sleep. Parents compare pre-hospitalization to the post-hospitalization status of each item on a scale of 1-5. Reliability was high as measured by a Chronbach alpha of 0.92 . Validity has been tested against an individual assessment by a psychiatrist with no significant difference.

${ }^{5}$ Index of clinical stress (ICS) is a standardized, 25 item self-report questionnaire that is administered to children of 12 years or older or young adults. It measures the degree of magnitude of the client's perception of stress. The reliability Chronbach alpha is 0.90 which indicates internal consistency. The standard error of measurement is 5.02 which indicates relative accuracy.

${ }^{6}$ Hamilton anxiety rating (HAM-A) uses 14 items that are scored $0-4,0=$ Not present; $4=$ Severe, with Total $=0-56$, where $<17$ indicates mild severity, 18-24 indicates moderate severity, and 25-30 moderate to severe. The scale has poor discriminatory ability between anxiety and other conditions and does not consist of standardized probe questions. It has acceptable reported IRR levels.

${ }^{7}$ Faces, legs, activity, cry, consolability pain scale (FLACC) is an observational instrument for reporting pain on children 2 months to 7 year old, or for those who cannot report pain. There are five categories face, legs, activity, cry, consolability scale. Scored 0-2. It translates into 0-10. IRR is 0.52-0.66 which is good.

${ }^{8}$ Wong-Baker faces pain scale by is a self-reporting scale. The child rates their pain on a scale of $0-5$. It has established validity. 


\section{Background}

More than five million children living in the United States (US) undergo surgical procedures each year, according to Perry et al. 2012 (cited in Goldschmidt and Woolley 2017, p. 256). Surgery invokes varied emotions in children and their caretakers. Emotions evoked in the preoperative period can be carried over into the postoperative period to several days after the procedure. These emotions can lead to disturbances in eating and sleeping patterns. Primary triggers for anxiety in caretakers can be the unfamiliar environment and role expectations. Parental anxiety can further heighten or cause anxiety in children.

Preoperative anxiety in children is a crucial predictor for postoperative issues. Surgical anxiety can elevate levels of blood cortisol as part of the stress response. This may increase the risk of infection and delay postoperative healing (Draskovic et al. 2014, p. 1). Children and adolescents with high levels of anxiety can experience higher levels of postoperative pain (Bringuier et al. 2009, pp. 737-744, Crandall et al. 2009, pp. 308-321, Kain et al. 2006, pp. 651-658).

Currently, many pediatric patients receive medications to reduce their anxiety before surgery. These medications are not equally effective in reducing anxiety for preschool age children (Chee 2011, p. 20). There is a need to identify other nonpharmacologic methods of anxiety relief in this population.

Several pharmacologic and nonpharmacological interventions have been evaluated for their efficacy to overcome the potential consequences of preoperative anxiety. Several studies have explored different distraction techniques in controlling preoperative anxiety in children.

Review and synthesis of the literature on these distraction approaches is expected to identify what are the effects of distraction techniques on pediatric preoperative anxiety and to pinpoint any need for improvement in the use of distraction for reducing children's anxiety.

\section{Methods}

The Preferred Reporting Item for Systematic reviews and Meta-analysis statement (PRISMA) flow diagram describes the article selection process (see Figure 1). The Participants, Interventions, Comparison, Outcome (PICO) model was used to formulate the research question for the current review and was used to identify the eligible articles

\section{Information Source and Search}

A systematic search was conducted in the databases PubMed and CINAHL from September 13 to September 30, 2019, following the Preferred Reporting Items for Systematic Review and Meta-analysis (PRISMA) guideline (see Figure 1). In PubMed, various combinations of Medical Subject Heading (MeSH) terms and keywords were used with Boolean operators to exclude and truncate, so that the most appropriate articles for the topic could be retrieved from academic 
journals (see Table 2). The search on PubMed with the phrase "preoperative anxiety in children and nursing" returned 156 articles.

Figure 1. PRISMA Prisma Flow Diagram

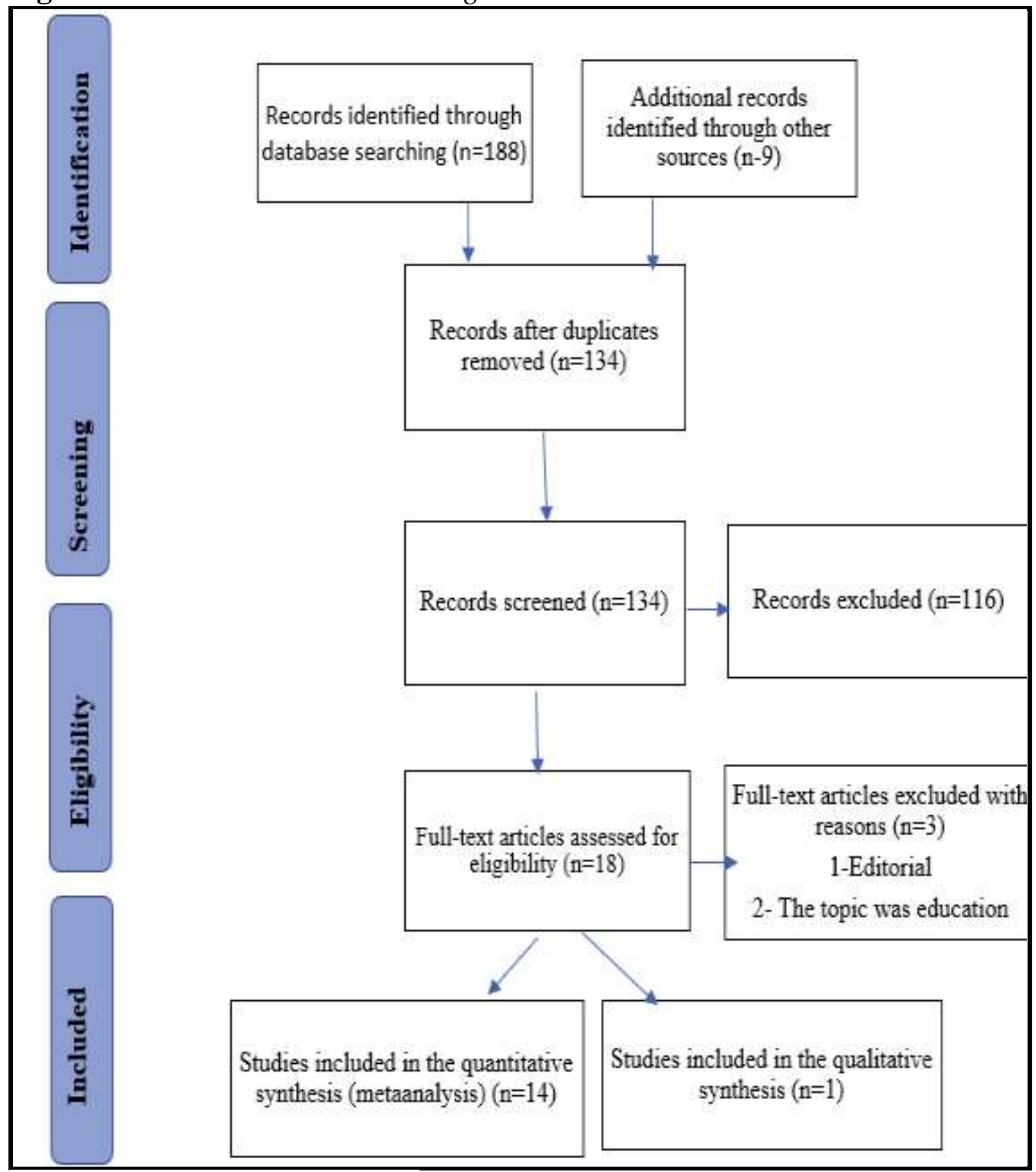

Source: Moher et al. 2009, p. e1000097.

In CINAHL, the subject headings and keywords were used similarly (see Table 2). The search was further limited to articles available in full text published between January 1, 2015, to December 31, 2019, written in English, peer-reviewed, and with studies conducted on children 3 to 12 years of age and published in academic journals. The search with these limiters returned 32 articles. 
Table 2. Database Search Table

\begin{tabular}{|c|c|c|}
\hline Databases & Search Terms & $\begin{array}{l}\text { Search } \\
\text { Results }\end{array}$ \\
\hline PubMed & $\begin{array}{c}\text { ((((““Anxiety/nursing”[Mesh] OR “Anxiety/surgery”[Mesh] OR } \\
\text { "Anxiety/distraction” [Mesh] ((surgery) AND pediatric) AND } \\
\text { anxiet* (year 2015-2019, English, humans, journal article) }\end{array}$ & 156 \\
\hline CINAHL & $\begin{array}{c}\text { (MH “Surgery, Operative+”) AND ((MH “Anxiety") OR } \\
\text { "anxiety") AND ((MH “Relaxation Techniques+") OR (AB } \\
\text { distract* OR AB alternative OR AB non-pharmacological OR } \\
\text { AB complementary OR AB integrative)) MH “Surgery, } \\
\text { Operative+") AND } \\
\text { ((MH “Anxiety”) OR “anxiety”) AND ((MH “Relaxation } \\
\text { Techniques+”) OR (AB distract* OR AB alternative OR AB } \\
\text { non-pharmacological OR AB complementary OR AB } \\
\text { integrative)) Full Text; Published Date: 20150101-20191231; } \\
\text { English Language; Peer-Reviewed, All child. }\end{array}$ & 32 \\
\hline
\end{tabular}

\section{Number of Articles}

The initial search of PubMed and CINAHL databases yielded 188 articles. Nine more records were identified through other sources. One hundred, thirty-four articles remained after removing duplicates. One hundred and sixteen articles were removed based on inclusion/exclusion criteria by reviewing titles and abstracts, after which 18 remained. After screening these full-text articles, three articles were further removed because one was an editorial, and two presented educational strategies only. A total of 15 articles were included in the analysis.

\section{Results}

\section{Evidence Level of the Studies}

The strength and quality of the literature were rated using the American Association of Critical Care Nurses (AACN) levels of evidence, 2012 (cited in Peterson 2014, p, 62). Twelve of the studies were rated as having A level of evidence. One of the studies was rated as having a $\mathrm{B}$ level of evidence. Two studies were rated at $\mathrm{C}$ level of evidence.

\section{Overview of the Studies}

The studies included in this review were diverse in their country of conduct. One study was conducted in the United States (Stewart et al. 2019, pp. 567-575). One study was conducted in Iran (Dehghan et al. 2019, pp. 1-7). Two studies were conducted in Turkey, (Bumin Aydin et al. 2017, pp. 27-31, Aytekin et al. 2016, pp. 56-62). Two studies were conducted in Brazil (Cumino et al. 2017, pp. 169175, Franzoi et al. 2016, p. e2841). Two studies were conducted in Italy (Vagnoli et al. 2019, pp. 913-921, Dionigi, and Gremigni 2017, pp. 632-640). One study was 
conducted in France (Marechal et al. 2017, pp. 247-253). One study was conducted in Egypt (Abd-Elshafy et al. 2015, pp. 1277-1284). A multi-site study was conducted in Jordan and United Arab Emirates (UAE) (Al-Yateem et al. 2016, pp. 572-581), and two studies were conducted in India (Noronha and Shanthi 2015, pp. 523-525, Kumar et al. 2019, pp. 1244-1250). Two studies were conducted in South Korea (Kim et al. 2015, pp. 778-784, Ryu et al. 2018, p. 284). None of the studies were found to be based on a theoretical model.

Data was collected on a wide variety of distraction techniques and different measures of anxiety levels. Fourteen studies focused on distraction techniques initiated in a hospital surgical unit, while only one, Bumin Aydın et al. (2017, pp. 27-31) was done at a clinic site. There were two multi-site studies. One was conducted in two hospitals, one in Jordan and the other in UAE (Al-Yateem et al. 2016, pp. 572-581), and one was done in selected hospitals in Mangalore, India (Noronha and Shanthi 2015, pp. 523-525).

Integrated clown intervention and art therapy was used to enhance the efficacy of oral medication therapy in reducing anxiety at the time of separation from parents (Dionigi, and Gremigni 2017, pp. 632-640). Story-telling and integrated art therapy was used where the parent narrated a custom made "Adam Goes to Surgery" story while the child colored in a coloring book related to the topic (AlYateem et al. 2016, pp. 572-581). The child played with "play doh" for six minutes in the preoperative area (Bumin Aydin et al. 2017, pp. 27-31). The child was offered a choice of computer games, books, or music for preoperative distraction (Aytekin et al. 2016, pp. 56-62). One group of children was distracted by watching cartoon videos, the other by parental presence, and a third by watching videos while parents were present (Kim et al. 2015, pp. 778-784). Children watched funny videos and played common games during their stay in the preoperative area (Kumar et al. 2019, pp. 1244-1250). Children listened to four preselected pieces of instrumental music that were non-lyrical, with $60-80$ beats per minute, with sound level $6 \mathrm{db}$, in low tones, performed on string instruments with minimal percussion (Franzoi et al. 2016, e2841). Children listened to taped popular songs selected by the child (Abd-Elshafy et al. 2015, pp. 1277-1284). Children were given books that contained pictures of preoperative, intraoperative and postoperative interventions (Noronha and Shanthi 2015, pp. 523-525), virtual reality (Ryu et al. 2018, p. 284), a 5-minute virtual reality exposure to the operating room (Dehghan et al. 2019, pp. 1-7). Children played with a smartphone in the preoperative holding area (Cumino et al. 2017, pp. 169-175). Children received relaxation-guided imagery from a psychologist (Vagnoli et al. 2019, pp. 913-921). Children played age-appropriate tablet game apps on an iPad (Marechal et al. 2017, pp. 247-253).

\section{Study Design}

Twelve studies were randomized controlled trials (RCT) (Vagnoli et al. 2019, pp. 913-921, Franzoi et al. 2016, p. e2841, Marechal et al. 2017, pp. 247-253, Kim et al. 2015, pp. 778-784, Stewart et al. 2019, pp. 567-575, Aytekin et al. 2016, pp. 56-62, Bumin Aydin et al. 2017, pp. 27-31, Abd-Elshafy et al. 2015, pp. 1277- 
1284, Cumino et al. 2017, pp. 169-175, Kumar et al. 2019, pp. 1244-1250, Dehghan et al. 2019, pp. 1-7, Ryu et al. 2018, p. 284). One study was a random controlled non-inferiority trial (Al-Yateem et al. 2016, pp. 572-581). One study was a quasi-experimental pre-test post-test control group experimental design (Noronha and Shanthi 2015, pp. 523-525). One was an observational study (Dionigi and Gremigni 2017, pp. 632-640).

\section{Sample}

All studies used a convenience sample of patients signed up for surgery at the selected site/sites. All studies recruited pre-school and school-age pediatric patients. The age of the children ranged from three to twelve years. The total sample size ranged from 30 to 168 . The size of the study groups and control groups ranged between 15 and 84. Parental anxiety was also assessed in some studies (Stewart et al. 2019, pp. 567-575, Kim et al. 2015, pp. 778-784, Franzoi et al. 2016, p. e2841, Kumar et al. 2019, pp. 1244-1250, Marechal et al. 2017, pp. 247-253).

\section{Pediatric Anxiety Measurements}

The primary outcome examined across the studies was, the preoperative anxiety of children. Anxiety was measured using various instruments, including the state-trait anxiety inventory for children (STAI-C) completed by parents (AlYateem et al. 2016, pp. 572-581, Aytekin et al. 2016, pp. 56-62, Kumar et al. 2019, pp. 1244-1250), and the modified yale preoperative assessment scale (mYPAS) completed by an observer (usually a researcher or psychologist) (AlYateem et al. 2016, pp. 572-581, Dionigi, and Gremigni 2017, pp. 632-640, Franzoi et al. 2016, p. e2841). Furthermore, Al-Yateem et al. (2016, pp. 572-581) measured the vital signs of children during each surgery phase. Kumar et al. (2019, pp. 1244-1250) measured the stress of children using the index of clinical stress (ICS) and the Ottawa mood scale 7.

Other tools utilized include the Wong-Baker faces pain $\operatorname{scale}^{8}$ for selfreporting pain (Franzoi et al. 2016, p. e2841), The faces, legs, activity, cry, consolability pain scale (FLACC) for observational assessment of pain (Vagnoli et al. 2019, pp. 913-921), and the measurement of serum cortisol as a stress marker (Kim et al. 2015, pp. 778-784, Kumar et al. 2019, pp. 1244-1250, Abd-Elshafy et al. 2015, pp. 1277-1284).

The children were assessed at different points of time during the perioperative period, which corresponded with identified periods of high anxiety. The initial assessment of anxiety was usually performed before separation, either in the waiting area or the anesthesia holding area; the second point of assessment was right after separation from parents; and the third point was at mask induction (Stewart et al. 2019, pp. 567-575). Some studies assessed the patient after emerging from anesthesia (Marechal et al. 2017, pp. 247-253, Abd-Elshafy et al. 2015, pp. 1277-1284). Some followed up with post-hospital behaviors (Stewart et al. 2019, pp. 567-575). Not all studies measured anxiety at all the identified points in time. 


\section{Distraction Techniques}

Various distraction techniques were explored to alleviate children's anxiety before surgery. The distraction techniques used with children in the experimental group included the following: A medical clown intervention and integrated art therapy (Dionigi and Gremigni 2017, pp. 632-640). The parent narrated a custommade "Adam Goes to Surgery" story while the child colored in coloring book related to the topic (Al-Yateem et al. 2016, pp. 572-581). The child played with "Play-doh" for six minutes in the preoperative area (Bumin Aydin et al. 2017, pp. 27-31). The child was offered a choice of computer games, books, or music for preoperative distraction (Aytekin et al. 2016, pp. 56-62). One group of children was distracted by watching cartoon videos, the other by parental presence, and a third by watching videos while parents were present (Kim et al. 2015, pp. 778784). Children watched funny videos and played common games during their stay in the preoperative area (Kumar et al. 2019 pp. 1244-1250). Children listened to four preselected pieces of instrumental music that were non-lyrical, with 60-80 beats per minute, with sound level $6 \mathrm{db}$, in low tones, performed on string instruments with minimal percussion (Franzoi et al. 2016, p. e2841). Children listened to taped popular songs selected by the child (Abd-Elshafy et al. 2015, pp. 1277-1284). Children were given picture books that contained preoperative, intraoperative and post-operative interventions (Noronha and Shanthi 2015, pp. 523-525). Children were exposed to vivid, immersive virtual reality preoperatively (Ryu et al. 2018, p. 284). A 5-minute virtual reality exposure to the operating room was given (Dehghan et al. 2019, pp. 1-7). Children played with a smartphone in the preoperative holding area (Cumino et al. 2017, pp. 169-175). Children received relaxation-guided imagery from a psychologist (Vagnoli et al. 2019, pp. 913-921). Children played age appropriate tablet game apps on an iPad during induction of anesthesia (Marechal et al. 2017, pp. 247-253, Stewart et al. 2019, pp. 567-575).

\section{Effects of Distraction Techniques}

Regardless of the distraction method utilized, most studies showed lower anxiety scores in the experimental group when distraction interventions were used compared to the control group. Three of the 15 studies (Bumin Aydin et al. 2017, pp. 27-31, Abd-Elshafy et al. 2015, pp. 1277-1284, Kumar et al. 2019, pp. 1244 1250 ) used distraction as an adjunct to medication.

Al-Yateem et al. (2016, pp. 572-581) discovered significantly less stress, anxiety, and pain and improved mood when a coloring book was utilized for distraction compared with no distraction. Vagnoli et al. (2019, pp. 913-921) similarly found a decrease in anxiety and pain post-surgery with the use of toys and video games as distraction methods.

Kumar et al. (2019, pp. 1244-1250) found patients in the post-intervention experimental group who had watched funny videos and played common games had significantly lower levels of serum cortisol during surgery, as compared to the control group. 
Abd-Elshafy et al. (2015, pp. 1277-1284) found that among pediatric patients of cardiac surgery, the plasma cortisol levels of the experimental group were lower than those of the control group, especially at sternotomy with fewer occurrences of surgery related PTSD, after the experimental group listened to music selected by the patients. The music started before induction of anesthesia and lasted till extubation. The control group only received pharmacological intervention.

Cumino et al. (2017, pp. 169-175) scored four groups of children on the mYPAS pre and post-intervention. The control group's parents were given only verbal education of the anesthetic procedure. The informed group parents also received an information booklet. The smartphone group parent received verbal education and the child received a smartphone to play within the holding area. The smartphone and informed group parent also received a booklet, and the child could play with a smartphone in the holding area. It was found that though preintervention anxiety levels were similar between the four groups, post-intervention anxiety in the control group was higher compared to all other groups $(\mathrm{p}=0.001)$.

Dehghan et al. (2019, pp. 1-7) exposed the experimental group to a 5-minute virtual reality tour of the operating room and scored the pre and post-intervention activity, vocalization, emotional expressivity, and state of apparent arousal of the control and experimental group. It was found that while only pre-intervention vocalization differed $(\mathrm{p}$-value $=0.019)$, there was a significant difference between the pre and post-intervention scores in all subscales ( $\mathrm{p}$-value $<0.05)$, except for the state of apparent arousal.

Ryu et al. (2018, p. 284) found that the baseline m-YPAS scores for the experimental and control group were similar, the post-intervention score for the experimental group, which was distracted with the use of virtual reality, was 28.3, while the score for the control group was 46.7, which was a significant difference.

Kim et al. (2015, pp. 778-784) found that there was no significant difference between the post-intervention anxiety scores of three groups of children aged 2-7year-old, that received video distraction only, parental presence only, and both video distraction and parental presence.

Franzoi et al. (2016, p. e2841) found that there was a significant difference between the baseline and post-intervention anxiety level of the experimental group ( $\mathrm{p}$-value $=0.0132$ ) that listened to music for 15 minutes, as compared to that of the control group ( $\mathrm{p}$-value $=0.8877$ ) that did not listen to any music.

Aytekin et al. (2016, pp. 56-62) studied several distraction strategies against a control group that received no anxiolytic intervention and found that the experimental group had a mean observed separation score, based on 3 measures, of 1.45, while the control group's was 2.02. The STAI-C State score of the experimental group was 53.95, while that of the control group was 56.37. This signified the experimental group had lower anxiety on both tests as compared to the control group.

Noronha and Shanthi (2015, pp. 523-525) studied distraction vs. unspecified routine care and found that during the pretest period, $80 \%$ of the experimental group experienced severe anxiety, while $60 \%$ of the control group experienced moderate to severe anxiety. In the post-test period, after the experimental group was exposed to picture books, only $53.33 \%$ of the experimental group had mild to 
moderate anxiety. The mean post-test anxiety score of the experimental group, (24.8+-2.09) was lower than the mean post-test anxiety score of the control group (30.7+-2.96).

Marechal et al. (2017, pp. 247-253) exposed the experimental group to tablet game apps on an iPad and found that m-YPAS and STAI-C were similar for both the study group and the control group at all 4 points of measurement.

\section{Discussion}

The traditional practice to prevent pre-operative anxiety has been the preoperative administration of anxiolytics and parental presence. Alternative and complementary use of distraction and other techniques has also been studied and found effective in the prevention of pre-operative anxiety (Dionigi and Gremigni 2017, pp. 632-640). The focus of this review was on distraction techniques that can be incorporated into a nursing care plan.

Data extracted from the reviewed studies indicated that children experience high anxiety in the preoperative period. Children were assessed at different points of time during the perioperative period, which corresponded with identified periods of high anxiety. The first assessment was usually performed before separation from parents, either in the waiting area or the anesthesia holding area. The second point of assessment was right after separation from parents and the third point was at mask induction. Some studies assessed the patient after emerging from anesthesia and some followed up at home.

Many studies cited that the control group received "standard care". There was, however, no consensus on what "standard care" or "routine care" was. Some studies indicated standard or routine care consisted of medication only, some indicated preoperative education, some a combination of both, and some even included toys. It is not possible to generalize results in the absence of a standardized variable.

Three of the 15 studies used distraction as an adjunct to medication (Bumin Aydin et al. 2017, pp. 27-31, Abd-Elshafy et al. 2015, pp. 1277-1284, Kumar et al. 2019, pp. 1244-1250). Five studies combined distraction with education (Aytekin et al. 2016, pp. 56-62, Cumino et al. 2017, pp. 169-175, Kumar et al. 2019, pp. 1244-1250, Noronha and Shanthi 2015, pp. 523-525, Ryu et al. 2018, p. 284). Two studies combined distraction with parental presence (Kim et al. 2015, pp. 778-784, Vagnoli et al. 2019, pp. 913-921). Four studies combined various distraction strategies (Aytekin et al. 2016, pp. 56-62, Dionigi and Gremigni 2017, pp. 632-640, Kumar et al. 2019, pp. 1244-1250, Cumino et al. 2017, pp. 169175). In some studies, routine care also included providing children with books and toys. All these additional variables might have confounded the influence of each distraction strategy and routine care on preoperative anxiety.

In some studies, parents, doctors, nurses, and in-serviced hospital staff rated anxiety on standardized scales, while other studies employed trained psychologists to do the rating. The degree of proficiency of the rater could have influenced the results. 
Most studies excluded children with mental disabilities, emotional problems, and those with a history of previous exposure to anesthesia. Currently, there is no or very little data available for these groups.

Five out of the fifteen articles were not generalizable due to the small size of the study sample (Abd-Elshafy et al. 2015, pp. 1277-1284, Cumino et al. 2017, pp. 169-175, Dehghan et al. 2019, pp. 1-7, Franzoi et al. 2016, p. e2841, Vagnoli et al. 2019, pp. 913-921).

Since surgery requires an extremely controlled environment, all studies were limited to the use of convenience samples which were facility-based. This also limited sample characteristics by specialty. Most patients were male, outpatient, elective surgery cases that were healthy. Only two studies were conducted on children undergoing heart surgery. There is a need to conduct studies focusing on female patients and those with high acuity.

The studies were conducted in countries that were diverse by geography, culture, and language (as explained in the overview of studies). Most researchers reported using translations of standardized instruments in local languages. There is a possibility of some interrater reliability having been lost across cultures and languages. There was, however, no study conducted in the Spanish language which is a major language spoken in the Americas. There is a need to conduct studies in the Spanish language to create data relevant to Spanish speaking children.

There was only one study carried out inside the United States (Stewart et al. 2019, pp. 567-575). There is a need for more studies to be carried out in the United States to incorporate the diverse cultural and linguistic needs of pediatric patients in this country.

\section{Implications for Nursing Practice}

Perianesthesia nursing staff can reduce anxiety in preoperative pediatric patients by facilitating role-play or play therapy using dolls and toys with child life specialists for younger children. School-age children may benefit most from touring the operating room before surgery, having coloring books to work on at home, days before surgery, or playing videogames while in the preoperative holding area.

Factors that ease implementation of the above techniques include taking time to administer teaching interventions, adequate staffing, budgetary allowances, maintaining awareness of teaching modalities, and willingness to accommodate new methods. Many surgical centers have designated pre-anesthesia clinics with the staffing and resources to implement these types of preoperative teaching modalities. Modalities, such as therapeutic play, touring the OR, role-play rehearsal, and specialized teaching performed by child life specialists, are simple to implement. These interventions can be used in the preoperative setting and in the postoperative recovery phase to emphasize reducing postoperative complications associated with anxiety. 
Distraction strategies come to fit all budgets, situations, and levels of care. They can be modified according to the age, physical and cognitive ability of the patient. They can be adapted for the requirements of the perioperative environment.

Nursing intervention is crucial for reducing anxiety in surgical patients and their parents. The non-pharmacological intervention is not inferior to the pharmacological intervention in alleviating anxiety. All nurses in the perioperative environment where children can become anxious should be trained to implement distraction-based interventions to minimize or eliminate the negative sequelae of anxiety as well as the use of anxiolytic medications.

\section{Limitations of this Literature Review}

After searching for three major databases and online resources, only fifteen articles met the inclusion and exclusion criteria and were included in this literature review. There is a risk that some studies were missed due to the selected databases and search items.

The review will provide preliminary empirical data that will form the basis for conducting large-scale multicenter studies on non-pharmacological interventions used to reduce preoperative anxiety in preschool and school-age children, the results of which may inform clinical practice.

Non-pharmaceutical preoperative anxiety reduction interventions have shown efficacy. It is, however, unknown whether clinicians would use them in practice. It is, therefore, important to evaluate and investigate, how clinicians view these non-pharmaceutical preoperative anxiety reduction interventions and whether they are willing to use them on their patients in clinical practice.

\section{Conclusion}

The findings from this literature review have revealed that distraction techniques can effectively decrease preoperative anxiety levels in pre-school and school-age children. Healthcare providers must incorporate the concept of distraction in their care of pediatric surgery patients. Further research with larger samples in various settings will help identify the best distraction techniques and, also to recognize whether these techniques have a positive outcome on postoperative care.

\section{References}

Abd-Elshafy SK, Khalaf GS, Abo-Kerisha MZ, Ahmed NT, Abd El-Aziz MA, Mohamed MA (2015) Not all sounds have negative effects on children undergoing cardiac surgery. Journal of Cardiothoracic and Vascular Anesthesia 29(5): 1277-1284.

Al-Yateem N, Brenner M, Shorrab AA, DochertyC (2016) Play distraction versus pharmacological treatment to reduce anxiety levels in children undergoing day surgery: a randomized controlled non-inferiority trial. Child: Care, Health, and Development 42(4): 572-581. 
Aytekin A, Doru Ö, Kucukoglu S (2016) The effects of distraction on preoperative anxiety level in children. Journal of PeriAnesthesia Nursing 31(1): 56-62. https://doi.org/10. 1016/j.jopan.2014.11.016 [Accessed: 17 September 2021]

Bringuier S, Dadure C, Raux O, Dubois A, Picot M, Capde (2009) The perioperative validity of the visual analog anxiety scale in children: a discriminant and useful instrument in routine clinical practice to optimize postoperative pain management. Anesthesia \& Analgesia 109(3): 737-744.

Bumin Aydın G, Yüksel S, Ergil J, Polat R, Akelma FK, Ekici MS, et al. (2017) The effect of play distraction on anxiety before premedication administration: a randomized trial. Journal of Clinical Anesthesia 36(Feb): 27-31.

Chee S (2011) Behavior modifying techniques to reduce perioperative anxiety in pediatric patients as an alternative to pharmacologic premedication. ProQuest Dissertations Publishing.

Crandall M, Lammers C, Senders C, Braun JV (2009) Children's tonsillectomy experiences: influencing factors. Journal of Child Health Care 13(4): 308-321.

Cumino DO, Vieira JE, Lima LC, Stievano LP, Silva RAP, Mathias LAST (2017) Smartphone-based behavioral intervention alleviates children's anxiety during anesthesia induction. European Journal of Anaesthesiology 34(3): 169-175.

Dehghan F, Jalali R, Bashiri H (2019) The effect of virtual reality technology on preoperative anxiety in children: a Solomon four-group randomized clinical trial. Perioperative Medicine 8(1): 1-7. (6)

Dionigi A, Gremigni P (2017) A combined intervention of art therapy and clown visits to reduce preoperative anxiety in children. Journal of Clinical Nursing 26(5-6): 632640.

Draskovic B, Stanic D, Uram-Benka A, Fabri I (2014) Stress indicators during general anesthesia with opioid analgesics in children. Turkish Journal of Medical Sciences 44(6): 1095-1102.

Franzoi MAH, Goulart CB, Lara EO, Martins G (2016) Music listening for anxiety relief in children in the preoperative period: a randomized clinical trial. Revista LatinoAmericana de Enfermagem 24(Dec): e2841.

Goldschmidt K, Woolley A (2017) Using technology to reduce children's anxiety throughout the perioperative period. Journal of Pediatric Nursing 36(Apr): 256-258.

Jenkins BN, Fortier MA, Kaplan SH, Mayes LC, Kain ZN (2014) Development of a short version of the modified Yale preoperative anxiety scale. Anesthesia and Analgesia 119(3): 643-650.

Kain ZN, Mayes LC, Caldwell-Andrews AA, Karas DE, McClain BC (2006) Preoperative anxiety, postoperative pain, and behavioral recovery in young children undergoing surgery. Pediatrics 118(2): 651-658.

Karling M, Stenlund H, Hägglöf B (2006) Behavioral changes after anesthesia: validity and reliability of the post-hospitalization behavior questionnaire in a Swedish pediatric population. Acta Paediatrica, International Journal of Paediatrics 95(3): 340-346.

Kim H, Jung SM, Yu H, Park SJ (2015) Video distraction and parental presence for the management of preoperative anxiety and postoperative behavioral disturbance in children: a randomized controlled trial. Anesthesia and Analgesia 121(3): 778-784.

Kirisci L, Clark DB, Moss HB (1997) Reliability and validity of the state-trait anxiety inventory for children in adolescent substance abusers: confirmatory factor analysis and item response theory. Journal of Child and Adolescent Substance Abuse 5(3): $57-69$.

Kumar A, Das S, Chauhan S, Kiran U, Satapathy S (2019) Perioperative anxiety and stress in children undergoing congenital cardiac surgery and their parents: effect of brief 
intervention-A randomized control trial. Journal of Cardiothoracic and Vascular Anesthesia 33(5): 1244-1250.

Marechal C, Berthiller J, Tosetti S, Cogniat B, Desombres H, Bouvet L, et al. (2017) Children and parental anxiolysis in pediatric ambulatory surgery: a randomized controlled study comparing $0.3 \mathrm{mg} \mathrm{kg}-1$ midazolam to tablet computer-based interactive distraction. British Journal of Anaesthesia 118(2): 247-253.

Moher D, Liberati A, Tetzlaff J, Altman DG (2009) Preferred reporting items for systematic reviews and meta-analyses: the PRISMA statement. PLoS Medicine 6(7): e1000097.

Noronha J, Shanthi S (2015) Effectiveness of picture books on preoperative anxiety among children (6-12 years) in selected hospitals at Mangalore. Asian Journal of Nursing Education and Research 5(4): 523-525.

Peterson MH, Barnason S, Donnelly B, Hill K, Miley H, Riggs L, Whiteman K (2014) Choosing the Best Evidence to Guide Clinical Practice: Application of AACN Levels of Evidence. Critical Care Nurse 34(2): 58-68.

Ryu J, Park J, Nahm FS, Jeon Y, Oh A, Lee HJ et al. (2018) The effect of gamification through virtual reality on preoperative anxiety in pediatric patients undergoing general anesthesia: a prospective, randomized, and controlled trial. Journal of Clinical Medicine 7(9): 284.

Stewart B, Cazzell MA, Pearcy T (2019) A single-blinded randomized controlled study on the use of interactive distraction versus oral midazolam to reduce pediatric preoperative anxiety, emergence delirium, and postanesthesia length of stay. Journal of Perianesthesia Nursing 34(3): 567-575.

University of Florida (2011) Hamilton anxiety rating scale (HAM-A). Retrieved from: https://dcf.psychiatry.ufl.edu/files/2011/05/HAMILTON-ANXIETY.pdf. [Accessed 18 September 2021]

Vagnoli L, Bettini A, Amore E, De Masi S, Messeri A (2019) Relaxation-guided imagery reduces perioperative anxiety and pain in children: a randomized study. European Journal of Pediatrics 178(6) 913-921.

WALMYR Publishing Company (n.d.) Index of clinical stress (ICS). Retrieved from: https://lifespanrespite.wildapricot.org/Resources/Documents/Performance_Measure ment_Tools/Index_of_Clinical_Stress.pdf. [Accessed 18 September 2021] 
